УДК 069.5:623.4(477)

DOI: $10.33099 / 2707-1383-2020-38-4-45-53$

Попельницька О.О., кандидат
історичних наук, завідувачка відділу
науково-видавничої діяльності,
Національний музей історї̈ України
(м. Київ, Україна)
ORCID: https://orcid.org/0000-0002-2719-2503

Шевченко О.В., завідувачка сектору «Декоративно-ужиткове мистечтво», Національний музей історії Украӥни (м. Київ, Украӥна)

\title{
3 ДОСВІДУ ПОБУДОВИ ВИСТАВКИ «ЗБРОЯ В КОЛЕКЦЇ̈ НАЦІОНАЛЬНОГО МУЗЕЮ ІСТОРІЇ УКРАЇНИ: ВІД ДАВНИНИ ДО СУЧАСНОСТІ»
}

\begin{abstract}
У статті характеризується виставка «Зброя в колекиії Національного музею історії Украӥни: від давнини до сучасності», яка у 2017-2019 роках діяла у Національному музеї історії України і на якій експонувались зброя та військове спорядження із фондових зібрань музею. Експонати виставки ілюстрували історію військової справи в Україні від найдавніших часів до сучасності. На виставиі були представлені також кращі взіриі історичної зброї, щуо походять із зібрань відомих колекціонерів кіния XIX - першої третини ХХ століть та нині перебувають у складі фондових зібрань НМІУ. Музейна виставка неодноразово привертала до себе увагу украӥнських ЗМІ та була популярна у відвідувачів музею.
\end{abstract}

Ключові слова: Національний музей історії Украӥни, військова історія, зброєзнавство, археологія, виставка, зібрання музею.

Наприкінці грудня 2016 р. у Національному музеї історії України (далі - НМІУ) була відкрита виставка «Зброя в колекції Національного музею історії України: від давнини до сучасності» [8-11; 14; 19]. Оскільки дефіцит експозиційних площ не дозволяє створити у НМІУ спеціалізований зброярський відділ (на кшталт Музею «Арсеналу» у Львові, Королівської збройової палати у Лондоні, Дрезденської збройової палати, Військового музею у Стамбулі, відділу зброї та обладунків Музею мистецтв «Метрополітен» тощо), створення тимча- сової виставки дозволило представити на огляд відвідувачів музею кращі раритети НМIУ.

Побудові виставки передувала дослідницька робота науковців експозиційних та фондових відділів НМІУ, які кілька років вивчали та атрибутували окремі предмети зброї та військового спорядження із музейного зібрання. Підсумком цих студій стали наукові публікації та доповіді на науково-практичних конференціях тощо [7; 12; $17 ; 21 ; 22 ; 24-32 ; 35-40]$. Після накопичення інформації про музейні предмети, які 
передбачалось відібрати для експонування, автори виставки ${ }^{1}$ приступили до створення концепції та структури майбутньої виставки. Крім демонстрації музейних предметів iз зібрання НМІУ, автори виставки мали на меті ознайомити широкий загал $з$ українською військовою історією від найдавніших часів до сьогодення.

Виклад основного матеріалу. Експонатами 16-ти вітрин виставки стали археологічні артефакти та історична зброя від середньовіччя до сучасності. Експонати було розміщено у вітринах за хронологічним принципом згідно археологічної та історичної періодизації. Деякі вітрини були тематичні: у них експонувались предмети із зібрань відомих колекціонерів (В.В. Тарновського, Б.І. Ханенка [3]) або такі, що походять із певних регіонів земної кулі Африки, Японії, Кавказу, Сходу тощо.

У вітринах № 1-4 експонувались виявлені на території України археологічні знахідки від найдавніших часів до XV ст. включно. У 1-й вітрині були представлені виявлені на місцях стоянок первісної людини часів середнього (датування: 100-40 тисяч років до нової ери) та пізнього (4010 тисяч років до н. е.) палеоліту кам'яні наконечники списів. Поряд експонувались шліфовані та висвердлені неолітичні кам'яні сокири (10-3 тисяч років до н. е.); кам'яні булави, бронзові ножі, сокири та кинджали доби бронзи (3-2 тисяч років до н. е.).

У 2-й вітрині була представлена зброя раннього залізного віку (1 тисячоліття до н. е. - перші століття н. е.), виявлена у похованнях скіфів та сарматів, що населяли степи України: бронзові, залізні та кістяні

1 Науковці НМІУ Ю.Г. Безкоровайна, М.М. Беленко, С.В. Діденко, Я.В. Затилюк, М.С. Осипенко, Б.К. Патриляк, О.О. Попельницька, О. О. Пукліна, Т. М. Радієвська, С.В. Сорокіна, О.В. Шевченко, О.О. Якубенко; автор тексту екскурсії О.О. Попельницька. наконечники стріл, дротиків та списів, залізні мечі та кинджали. Значний науковий інтерес становили виявлені у похованні III ст. н. е. поблизу с. Волиця на Тернопільщині предмети давньо-германського захисного та наступального озброєння: ритуально пошкоджений залізний меч (тричі зігнений), бойовий ніж, наконечник списа, умбон та руків'я дерев'яного щита [7].

У 3-й вітрині експонувалась зброя війська Києворуської держави (X-XIII ст.), зокрема каролінгський меч кінця X - першої половини ХІ ст., у 1890 р. виявлений поблизу с. Хвощове на Полтавщині. Написи на клинку цього меча («коваль» та «Людота»)деякі дослідники трактують як клеймо майстра-мечника [4, с. 312-313; 15]. У вітрині також експонувались залізні сокири, бронзові булави та гирки-кистені, залізні наконечники стріл та навершя кавалерійської піки, кінські вудила та стремена.

Зброю кочових народів, які у XI-XIII ст. населяли український степ, репрезентувала виявлена у 1894 р. у половецькому кургані поблизу м. Таганча (Черкащина) шабля [16, Каталог находок. Сабли XI-XIII вв. (Сохранились полностью или частично). - № 74; 34, с. 26, табл. I. 5]. Поряд експонувались залізна кольчуга та шолом, у 1989 р. виявлені у половецькому похованні XII ст. у с. Стовпове Джанкойського р-ну АР Крим [20] та антропоморфне забрало шолома, у 1897 р. виявлене у половецькому курганному поховані XII-XIII ст. поблизу с. Ковалі (Канівщина) [6, с. 122-124; 33].

У вітрині № 4 було експоновано озброєння часів перебування українських земель у складі Великого князівства Литовського: знайдені у різних регіонах України археологічні мечі XIV-XV ст. [29], кольчуга та західноєвропейські мечі XV-XVI ст.

У 5-й вітрині була представлена зброя часів перебування українських земель у складі держави Річ Посполита (з 1569 р. 
до XVIII ст.), коли серед української еліти поширилась традиція носіння парадних (кунтушевих) шабель: польська «шабля орла» та меморіальна шабля, виготовлена 3 нагоди перемоги над турками у битві під Віднем (1683). Також експонувались стремена, шпори, шолом-капеліна та декорований золотінням нагрудник кіраси, що належали до захисного озброєння і військового спорядження польської важкої кавалерії часів Української національної революції середини XVII століття.

У вітрині № 6 було репрезентовано зброю українського козацтва XVIXVIII ст.: молоти-келепи, списи, пістолі, кинджали, турецькі та іранські шаблі. Поряд експонувались військові символи козацької старшини - булава [39] та пернач iз тригранним стилетом у руків’і. Турецькі та Іранські перначі (буздигани) другої половини XVII ст.з прихованим у руків'ї кинджалом, зберігаються у Музеї Війська Польського у Варшаві, Королівському замку Вавельу Кракові, зібранні Державного Ермітажу у Санкт-Петербурзі [43; 44; 48; 52, s. 84]. Перначі, за формою та дизайном подібні до того, що зберігається у НМІУ, у XVII-XVIII ст. виготовляли львівські зброярі-вірмени.

У вітрині № 7 відвідувачі виставки могли оглянути парадний обладунок італійського вершника-кірасира початку XVII ст., у 1890 р. придбаний відомим збирачем старовини Б. Ханенком у Римі на аукціоні колекції відомого антиквара Р. Річардса. До 1941 р. цей обладунок експонувався у Відділі зброї Центрального історичного музею України [26] (попередника НМІУ). Наплічники лицарських лат, що експонувались на виставці, прикрашені накладними позолоченими розетами. На нагруднику кіраси гравіюванням та позолотою зображено медальйон із постаттю Діви Марії. Латні рукавиці обладунку з пальцями рухомої кон- струкції пристосовані для натискання на курок карабіна або кавалерійського пістоля [28; 30].

Вітрина № 8 репрезентувала західноєвропейську спортивну та парадну зброю XVI-XVII ст.: декоровані мисливські аркебузу та арбалет,а також прикрашений гравійованими гербами саксонських міст рейково-редукторний пристрій для натягання тятиви арбалета. У вітрині експонувалисьі камзольні шпаги XVIII - початку XIX століття, декоровані у художніх стилях рокайль та класицизм.

У 9-й вітрині експонувалась зброя Африканського континенту XIX-XX ст., зокрема спис ассегай (або абіссінський спис) [41]. Традиційною холодною зброєю кабілів (народу, що належать до берберської спільноти та мешкає у Алжирі)був меч iз односічним клинком, який французькі колонізатори, за назвою східної групи кабілів «Iflissen Lebhar», називали флісса [46]. На форму клинка флісси справив вплив ятаган, що потрапив до Алжиру у XVIXVIII ст. $з$ Туреччини. Традиційним мечем туарегів - кочового народу берберської групи,що мешкає у пустельних районах Центральної Сахари (територія сучасного Алжиру, Лівії, Малі, Нігерії) є такуба [51], на привізному клинку якого наявні клейма європейських центрів виробництва холодної зброї.

Виставкова вітрина № 10 репрезентувала військове мистецтво середньовічної Японії. У ній експонувались однолезові мечі катана, вакідзасі та таті. Орнаментальним мотивом декорупіхов експонованого таті XIX ст. є емблема японських імператорів - геральдична хризантема. Подібні зображення зазвичай наявні на парадних мечах придворних сановників високого рангу [32].

У декорі представленого на виставці короткого меча вакідзасі (XVIII - першої 
половини XIX ст.) присутні символи державної релігії Японії у X-XIX ст. - буддизму. На клинку цього меча гравійоване зображення японського буддійського божества Фудо-Мьо-о, яке, зокрема, вважалось покровителем воїнів-самураїв [24; 25].

У цій же вітрині експонувалась фітильна парадна аркебуза XVII-XVIII ст., декорована гравійованими посрібленими зображеннями драконів, ієрогліфічними написами та геральдичними емблемами кланів Мінамото та Токугава [31].

У 11-й вітрині була представлена зброя країн Сходу XVI-XVIII ст., зокрема національні види шабель: іранський шамшир та турецький клич (кілідж). Експонувались і популярні у багатьох країнах ножі-ятагани (що виникли як зброя турецьких піхотинців-яничар) [40], а також кинджали різних типів: кавказький (з прямим клинком) та арабо-іранський (викривлений), який у різних країнах мав назву джамбія, ханджарабо бебут [5, с. 134; 27; 38].

У цій же вітрині експонувався парадна індо-іранська зброя XVII-XIX ст., оздоблена рослинним орнаментом, зображеннями живих істот та написами арабською в'яззю: декорована золотою насічкою сокиратабар (табарзин), щитдхаліз чотирма умбонами, шолом кулах-кхудіз кольчужною бармицеюта наруч базубанд $[42 ; 45 ; 49 ; 50]$.

У вітрині № 12 була представлена зброя Кавказу XIX - початку XX ст.: шашки [35; 36], кинджали камата бебут (із прямим та викривленим клинками), оздоблені кістяними і перламутровими інкрустаціями та срібними накладками рушниці,оправлені у срібло пістолі з ударно-кремінними замками і кістяними «яблуками» на руків'ях.

У вітрині № 13 відвідувачі виставки могли оглянути взірці колекційної мисливської зброї та спорядження XVIII-XIX ст.: двоствольні пістонні рушниці $з$ ударним замком, німецький мисливський кинджалхіршфангер (з нім. «ловець оленів») [47] та ріг для пороху, декорований різьбленою фігурою єдинорога.

Вітрина № 14 репрезентувала взірці російської, австро-угорської та німецької зброї часів Української революції 19171921 pр. Нею озброювались українські національні збройні формування (легіон Українських січових стрільців, війська Української держави, УНР та ЗУНР): гвинтівки систем Мосіна та Манліхера;пістолети систем Штаєра, Люгера («Parabellum») та Маузера (з дерев'яною кобурою-прикладом); російська драгунська шашка та німецька артилерійська шабля [21;22].

У вітрині № 15 експонувались взірці радянської та німецької зброї, якою у роки Другої світової війни озброювалась Українська повстанська армія: гвинтівки систем Мосіна та Токарєва (СВТ-40); пістолети-кулемети систем Судаєва, Шпагіна, Дєгтярьова (ППС-43, ППШ-41, ППД-40) та Фольмера; револьвер системи Нагана; пістолети «ТТ» (Тульський-Токарєва), «Вальтер» та «Parabellum» [37].

У вітрині № 16 була представлена сучасна зброя, яку ЗСУ використовують під час проведення Антитерористичної операції та Операцій об’єднаних сил на Сході України: пускові пристрої до реактивних протитанкових гранатометів одноразового використання РПГ-18 та РПГ-22. Експонувалось також захисне озброєння: каска (СШ-68) та бронежилет учасника АТО - науковця НМІУ Максима Осипенка, у 2014 р. призваного до лав ЗСУ.

Вище перелічені музейні предмети демонструвались у вітринах разом із супровідними етикетками, у яких були зазначені відомості про кожен із експонатів виставки. На початку огляду виставки розташовувався банер із текстом про історію формування збройового зібрання НМУ та його рари- 
тети, що були представлені у виставковому залі.

Висновки. Виставка історичної зброї та військового спорядження у НМIУ за час своєї майже трирічної діяльності (з грудня 2016 р. до вересня 2019 р.) привертала до себе увагу ЗМI, а також користувалась популярністю у відвідувачів музею, які відвідували анонсовані у соціальних мережах екскурсії. Екскурсії були проведені і для учасників Програми підвищення кваліфікації працівників музеїв «Експертиза культурних цінностей (предметів нумізматики, холодної та вогнепальної зброї)» (07.06.2017) та учасників Щорічних науково-практичних конференцій за результатами роботи НМІУ у 2017 та 2018 роках.

Під час проведення екскурсій науковці НМІУ знайомили екскурсантів із основними етапами мілітарної історї України, роз- повідали про найбільш цікаві експонати (шляхи їхнього потрапляння до музею, обставини виявлення археологічних артефактів, особливості практичного застосування та художнього декорування тощо). Під час екскурсій відбувалось двостороннє спілкування екскурсоводів та екскурсантів, оскільки чимало експонатів виставки викликали жваву дискусію і обговорення аудиторії, яка висловлювала власні міркування $з$ того чи іншого питання.

Досвід створення подібного виставкового проекту продемонстрував значний потенціал зброєзнавчих виставок, які сприяють рекламі музею та приваблюють відвідувачів, яких цікавлять різні аспекти історії в цілому та військової справи зокрема: батьків із дітьми, студентів, професійних істориків та археологів, колекціонерів, учасників руху історичних ре конструкторів тощо $[1 ; 2 ; 13 ; 18 ; 19 ; 23]$.

\section{СПИСОК ВИКОРИСТАНИХ ДЖЕРЕЛ І ЛІТЕРАТУРИ}

1. Авторська екскурсія «Зброя у колекції НМІУ: від давнини до сучасності», 25 червня[Анонс екскурсіі]] / [Електронний ресурс]. — Режим доступу: https://nmiu.kontramarka.ua/ widget/excursion/161 (дата звернення: 15.06.2020). - Назва з екрана.

2. Авторська екскурсія Олени Попельницької виставкою зброї НМІУ, 11 лютого 2018 р. [Анонс екскурсії] / [Електронний ресурс]. - Режим доступу: https://kyiv-online.net/events/ outing/avtorska-ekskursiya-oleny-popelnytskoji-vystavkoyu-zbroji-nmiu-2 (дата звернення: 15.06.2020). - Назва з екрана.

3. Акт від 19 лютого [1937р.], Київ, Музей Західнього мистецтва, вул. Чудновського. Складено цього акта в тому, що, на підставі розпорядження Музейного Відділу Українського Управління у справах Мистецтв при [Раднаркомі] УРСР, від 25 січня 1937 р., інд. 70/8, Музей Західнього мистецтва, у особі ст. наукового співробітника проф. Гілярова С. О. передав Центральному Історичному Музею, в особі наукового співробітника Музею Маєвського В. А. (завідувач Відділу зброї) (доручення ЦІМ № 7, від 28/1 - 37 р.) старовинну зброю, що зберігалася у Музеї Західнього мистецтва, Західню, Східню, Російську, а саме $<\ldots>$ // Науковий архів Національного музею мистецтв імені Богдана та Варвари Ханенків. - Оп. 1. - Спр. 44 - Арк. 295.

4. Андрощук Ф., Зоценко В. Скандинавские древности Южной Руси. Каталог. - Paris, 2012. $-367 \mathrm{c}$. 
5. Аствацатурян Э.Г. Турецкоеоружие в собрании Государственного исторического музея. - Санкт-Петербург, ООО «ТПГ «Атлант»», 2002. — 336 с.

6. Бобринский А.А. Курганы и случайные находки близ местечка Смелы. Дневники раскопок 1889-1897 гг. гр. Алексея Бобринского [и о курганах Звенигородского, Каневского и Роменского уездов]. - Санкт-Петербург, 1901. - Т. III. - 174 с. С. 122-123.

7. Вакуленко Л. В., Безкоровайна Ю. Г., Прокопенко В. М. Пшеворське поховання зі зброєю (новіна дходження до фондів Національного музею історії України) // Науковий вісник Національного музею історії України. Мат-ли щорічної наук.-практ. конф. Національного музею історії України. - Вип. 3. Зб. наук. праць пам’яті Володимира Михайловича Хардаєва (1952-2018), відомого дослідника історії ранніх слов’ян і Київської Русі, завідувача філіалу Національного музею історії України - Музею історичних коштовностей України. — Київ: Національний музей історії України, 2018. - С. 86-93.

8. Відкриття виставки «Зброя у колекції НМІУ: від давнини до сучасності» 16 січня 2017 / [Електронний ресурс]. — Режим доступу: https://kyiv-online.net/events/arts/vidkryttyavystavky-zbroya-u-kolektsiji-nmiu-vid-davnyny-suchasnosti (дата звернення: 15.06.2020). — Назва з екрана.

9. Виставка зброї в Національному музеї історії України / [Електронний ресурс]: Українська Військова Історія / Ukrainian Military History. — Режим доступу: https://www. ucrainarma.org/novini/vystavka-zbroji-v-nmiu.html (дата звернення: 15.06.2020). — Назва з екрана.

10. Виставка «Зброя у колекції НМІУ: від давнини до сучасності» 16 січня 2017 p. / [Електронний peсурс].- Режим доступу: https://www.facebook.com/eve

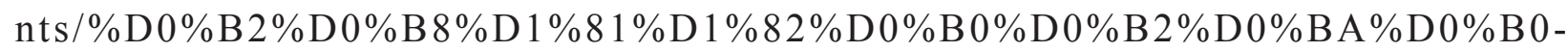
$\%$ D0 $\%$ B $7 \%$ D0\%B1\%D1\%80\%D0\%BE\%D1\%8F-\%D1\%83-\%D0\%BA\%D0\%BE\%D0\%BB $\%$ D0 $\%$ B5\%D0\%BA\%D1\%86\%D1\%96\%D1\%97-\%D0\%BD $\%$ D0\%BC\%D1\%96\%D1\%83$\%$ D0\%B2\%D1\%96\%D0\%B4-\%D0\%B4\%D0\%B0\%D0\%B2\%D0\%BD\%D0\%B8\%D0\%BD\% D0\%B8-\%D0\%B4\%D0\%BE-\%D1\%81\%D1\%83\%D1\%87\%D0\%B0\%D1\%81\%D0\%BD\%D0 $\% \mathrm{BE} \% \mathrm{D} 1 \% 81 \% \mathrm{D} 1 \% 82 \% \mathrm{D} 1 \% 96 / 1320386834650737$ (дата звернення: 15.06.2020). — Назва з екрана.

11. Вперше за сто років Національний музей історії України покаже свою колекцію зброї та обладунків / [Електронний ресурс]. — Режим доступу: http://visnik-press.com.ua/?p=71733 (дата звернення: 15.06.2020). - Назва з екрана.

12. Діденко С.В., Шевченко О.В. Колекція зброї та військового спорядження у збірці НМІУ // Скарбниця української культури. Науковий часопис. - Вип. 15 (Збірник матеріалів наукової конференції «Колекціонування українських старожитностей як складова частина українського національного руху і національного відродження XIX - поч. XX ст.»). Чернігів, 2013. - С. 220-223.

13. Екскурсія «Зброя та військове спорядження в колекції НМІУ: від давнини до сучасності» пройде 27 травня[Анонс екскурсіі] / [Електронний ресурс]. - Режим доступу: https:// nmiu.com.ua/anonsy-museum/766-ekskursiia-zbroia-ta-viiskove-sporiadzhennia-v-kolektsiinmiu-vid-davnyny-do-suchasnosti-proide-27-travnia (дата звернення: 15.06.2020). — Назва 3 екрана. 
14. Зброя у колекції НМІУ: від давнини до сучасності / [Електронний ресурс]. — Режим доступу: https://nmiu.com.ua/novyny/389-zbroia-u-kolektsii-nmiu-vid-davnyny-do-suchasnosti (дата звернення: 15.06.2020). — Назва з екрана.

15. Кирпичников А.В. Древнейший руський подписной меч // Советская археология. 1965. — № 3. - С. 196-201.

16. Кирпичников А.Н. Древнерусское оружие. - Вып. 1. Мечи и сабли IX-XIII вв. // Свод археологических источников. - Е 1-36. - Москва - Ленинград: Наука, 1966. - 143 с.

17. Колекція зброї та військового спорядження [Текст] = The weaponsand military equipment collection of the National Museum of the History of Ukraine: альбом / [упорядкув. Т. М. Радієвської та ін.; вступ. ст. С. В. Діденка, О. В. Шевченко; фотозйомка Д. В. Клочка]; Нац. музей історії України. - Київ: Мистецтво, 2011. - 63 с.: іл.

18. Куди піти 17 березня / Екскурсія «Зброя та військове спорядження» [Анонс екскурcii] / [Електронний ресурс]: «Новини» - Об'єктивна організація новин. - Режим доступу: https://novyny.org/2019/03/16/kudy-pity-17-bereznia (дата звернення: 15.06.2020). — Назва з екрана.

19. Національний історичний музей України. Виставка «Зброя у колекції НМІУ: від давнини до сучасності» / [Електронний ресурс]: Військово-історичний фотомузей. Режим доступу: http://museum.velizariy.kiev.ua/kiev/nimu_v3/index.html (дата звернення: 15.06.2020). - Назва з екрана.

20. Панченко М.В. К вопросу о датировании кочевнических древностей средневековья / [Электронный ресурс]: Восточноевропейский археологический журнал. - 1999. — № 1. Режим доступа: http://archaeology.kiev.ua/journal/011299/panchenko.htm (дата обращения: 15.06.2020). - Название с экрана.

21. Патриляк Б.К. Стрілецька зброя доби Українських визвольних змагань 1917-1921 pр. у зібрання Національного музею історії України // Науковий вісник Національного музею історії України. Зб. наук. пр. / Відп. ред. Б.К. Патриляк. - Вип. 2. - Київ, 2017. - С. 166-172.

22. Патриляк Б.К. Холодна зброя доби Українських визвольних змагань 1917-1921 pp. у зібрання Національного музею історії України // Науковий вісник Національного музею історії України. Зб. наук. пр. / Відп. ред. Б. К. Патриляк. - Вип. 3. - Київ, 2018. - С. 151156.

23. Повторення авторської екскурсії Олени Попельницької виставкою зброї НМІУ, 12 лютого[Анонс екскурсії] / [Електронний ресурс]. - Режим доступу: https://nmiu.com. ua/novyny/416-povtorennia-avtorskoi-ekskursii-oleny-popelnytskoi-vystavkoiu-zbroi-nmiu-12liutoho (дата звернення: 15.06.2020). - Назва з екрана.

24. Попельницька О. Антон Казимирович Левкович - перший директор Центрального історичного музею у Києві: 1935-1937 pp. // Науковий вісник Національного музею історії України: зб. наук. пр.: у 2 частинах. - Вип. 1.- Частина друга / Відп. ред. Б. К. Патриляк. Київ: Національний музей історії України, 2016. - С. 31-41.

25. Попельницька О. Буддійський символізм декору вакідзасі другої половини XVIIIXIX ст. із зібрання Національного музею історії України // Східний світ. - Київ, 2015. № 3. - С. 86-97.

26. Попельницька О. Відділ зброї Центрального історичного музею України (19361941) // Науковий вісник НМІУ. - Вип. 6. - Київ, 2020 (у друці). 
27. Попельницька О. Зброя східного походження з колекції Б. І. Ханенка у зібранні НМІУ // Мистецтво ісламу в музеях України: збірник матеріалів наукового семінару на честь 120-річного ювілею Марії Вязьмітіної (1896-1994). 25-26 квітня, 2016 р. / Національний музей мистецтв ім. Богдана та Варвари Ханенків. - Київ: Фенікс, 2017. - С. 90-98.

28. Попельницька О. Зброя та предмети озброєння із зібрань італійських антикварів XIX ст. Р. Річардса та А. Альберічі у колекції Національного музею історії України // Науковий вісник Національного музею історії України: зб. наук. пр. - Вип. 2 / Відп. ред. Б. К. Патриляк. — Київ: Левада, 2017. - С. 112-127.

29. Попельницька О. Мечі другої половини XIII - першої половини XV ст. у зібранні Національного музею історії України // Історія давньої зброї. Дослідження 2014: зб. наук. пр. - Київ: Інститут історії України НАНУ, 2014. - С. 149-163.

30. Попельницька О. Півдоспіх Франциска Медичі другої половини XVI ст. та італійські лати вершника початку XVII ст. у зібранні Національного музею історії України // Історія давньої зброї. Дослідження 2016: збірник наукових праць / Упоряд. Д. В. Тоїчкін; Ред. кол.: М. Ф. Дмитрієнко (голова), Г. В. Боряк, Д. В. Тоїчкін, В. В. Томозов, М. М. Хорасані, В. М. Прокопенко, Я. О. Іщенко. НАН України. Інститут історії України. - Київ, 2017. C. 382-399.

31. Попельницька О. Японська парадна гнотова аркебуза XVII-XVIII ст. у зібранні Національного музею історії України // Сходознавство. - № 69. - Київ: Інститут сходознавства ім. А. Ю. Кримського НАН України, 2015. - С. 77-85.

32. Попельницька О. Японський меч таті другоїполовини ХІХст.іззібрання Національного музею історії України // Східний світ / Інститут сходознавства ім. А. Ю. Кримського НАН України. - 2016. — № 2-3. - С. 184-196.

33. Пятышева Н.В.Железная маска из Херсонеса (К вопросу о происхождении и назначении кочевнических шлемов с масками). - Москва: ГИМ, 1964. — 64 с.

34. Собрание Б.И. и В.Н. Ханенко. Древности Приднепровья. Эпоха славянская (VIХІІІ вв.). - Вып. V. - 63 с.

35. Шевченко В. Кавказька шашка кінця XIX - початку XX ст. із колекції Національного музею історії України та доля іiї власника // Науковий вісник Національного музею історії України. Зб. наук. пр. / Відп. ред. Б. К. Патриляк. - Вип. 3. - Київ, 2018. - С. 366-378.

36. Шевченко В. Шашки майстра Османа Омарова із колекції Національного музею історії України // Третя Міжнародна зброєзнавча конференція: тези доповідей (Київ, 12-14 червня, 2018 року). - С. 36-38.

37. Шевченко О.В. Зброя Другої світової війни в колекції національного музею історії України // Науковий вісник Національного музею історії України. Зб. наук. пр. / Відп. ред. Б. К. Патриляк. - Вип. 6. - Київ, 2020 (у друці).

38. Шевченко О.В. Зброя та військове спорядження мусульманських країн в колекції НМІУ // Мистецтво ісламу в музеях України: зб. матеріалів наук. семінару Нац. музей мистецтв ім. Б. та В. Ханенків. - Київ, 2017. - С. 99-103.

39. Шевченко О.В. Чернігівські старожитності в колекції зброї НМІУ // Історія давньої зброї. Дослідження 2018 / упор. Д. Тоїчкін; Інститут історії України НАН України. — Київ: Інститут історії України НАНУ, 2018. - С. 315-319/ 
40. Шевченко О.В., Джулай М.В. Ятагани 3 колекції НМІУ // Науковий вісник Національного музею історії України. Зб. наук. праць / Відп. ред. Б. К. Патриляк. - Вип. 1. - Ч. 2. - Київ, 2016. - С. 343-348.

41. Assegai / [Electronic resource]: Wikipedia. — Access mode: https://en.wikipedia.org/wiki/ Assegai (lastaccess: 19.06.2020). — Titlefromthescreen.

42. BazuBand / [Elektronische Ressource]: Wikipedia. — Zugriffsmodus: https://de.wikipedia. org/wiki/Bazu_Band (DatumBerufung: 19.06.2020). — NamevomBildschirm.

43. Buzdygan / [Zasoby elektroniczne]: Wirtualne Muzea Małopolski. — Trybdostępu: http:// muzea.malopolska.pl/obiekty/-/a/4869610/4889605 (data odwołania: 19.06.2020). — Tytułekranu.

44. Buzdygan Stanisława Jana Jabłonowskiego / [Zasoby elektroniczne]: Muzeum Wojska Polskiego. - Trybdostępu: http://www.muzeumwp.pl/emwpaedia/buzdygan-stanislawa-janajablonowskiego.php (data odwołania: 19.06.2020). — Tytułekranu.

45. Dhal (shield) / [Electronic resource]: Wikipedia. - Access mode: https://en.wikipedia.org/ wiki/Dhal_(shield) (lastaccess: 19.06.2020). — Titlefromthescreen.

46. Flyssa / [Electronic resource]: Wikipedia. — Access mode: https://en.wikipedia.org/wiki/ Flyssa (lastaccess: 19.06.2020). — Titlefromthescreen.

47. Hirschfänger / [Elektronische Ressource]: Wikipedia. - Zugriffsmodus: https:// de.wikipedia.org/wiki/Hirschf\%C3\%A4nger (Datum Berufung: 19.06.2020). — Namevom Bildschirm.

48. KALENDARIUM DZIEJÓW ORĘŻA POLSKIEGO / [Zasoby elektroniczne]: Muzeum Wojska Polskiego. - Trybdostępu: http://www.muzeumwp.p1/kalendarium/10-20 (dataodwołania: 19.06.2020). - Tytułekranu.

49. Kulahkhud / [Electronic resource]: Wikipedia. — Access mode: https://en.wikipedia.org/ wiki/Kulah_khud (lastaccess: 19.06.2020). — Titlefromthescreen.

50. Tabar (axe) / [Electronic resource]: Wikipedia. — Access mode: https://en.wikipedia.org/ wiki/Tabar_(axe) (lastaccess: 19.06.2020). — Titlefromthescreen.

51. Takoba / [Electronic resource]: Wikipedia. — Access mode: https://en.wikipedia.org/wiki/ Takoba (lastaccess: 19.06.2020). — Titlefromthescreen.

52. Soldatenko A. Kolekcjabronipolskiej w ArsensleErmitazu // Muzealnictwo. — № 34. 1992. - S. 78-85. 